Introduction: The purpose of the present study was to characterise patients with breast cancer (BC) and NOD2-mutation (age $\geq 50$ years) according to their clinicopathological factors or family history. Patients aged $\geq 50$ years were compared with the control group and with NOD2-mutation carriers aged $<50$ years.

Material and methods: Prognostic factors were analysed in patients with $\mathrm{BC}$ with confirmed NOD2 c.3016_3017insC $(n=150)$ mutations. The control group was selected from patients with BC without mutations $(n=376)$.

Results: There were significant differences between NOD2-mutation carriers and the control group aged $\geq 50$ years, according to HER2 overexpression $(p=0.0001)$, ER $(-)$ $(p=0.007)$, PR $(-)(p=0.003)$, T1T2 $(p=0.011)$, and G3 $(p=0.036)$. Similarly, significant differences were observed between NOD2-mutation carriers and the control group aged $<50$ years, according to HER2 overexpression $(p=0.0001)$, ER $(-)$ $(p=0.049)$, and $N(+)(p=0.038)$. In patients aged $\geq 50$ years, family history of cancer, including BC, was observed more often in NOD2-mutation carriers compared with the control group of patients $(\mathrm{OR}=1.66$; $p=0.072$, for $\mathrm{BC}$ in family history: $\mathrm{OR}=2.65 ; p=0.002)$. NOD2-mutation carriers aged $\geq 50$ years had significantly less frequent G3 $(p=0.004)$ and HER2 overexpression ( $p=0.043)$ compared with patients with NOD2 mutation aged $<50$ years.

Conclusions: The presence of the NOD2 mutation is not only characteristic of younger patients but also in patients $>50$ years of age. In NOD2-mutation carriers aged $\geq 50$ years, the presence of larger tumour size, G3, or HER2 overexpression were lower compared with younger patients with NOD2 mutation.

Key words: breast cancer, NOD2 mutation, family history of cancer.

Contemp Oncol (Pozn) 2020; 24 (2): 79-86 DOI: https://doi.org/10.5114/wo.2020.97475

\section{Clinicopathological characteristics of breast cancer patients with NOD2 mutation according to age}

\author{
Joanna Huszno ${ }^{1}$, Zofia Kolosza ${ }^{2}$, Marta Nycz-Bochenek ${ }^{1}$, Małgorzata Lisik ${ }^{1}$, \\ Magdalena Mazur ${ }^{3}$, Jolanta Pamuła-Piłat ${ }^{3}$, Ewa Grzybowska ${ }^{4}$
}

\begin{abstract}
${ }^{1}$ Genetic Outpatient Clinic, Maria Skłodowska-Curie National Research Institute of Oncology Gliwice Branch, Poland

${ }^{2}$ Department of Biostatistics and Bioinformatics, Maria Skłodowska-Curie National Research Institute of Oncology Gliwice Branch, Poland

${ }^{3}$ Department of Genetic and Molecular Diagnostics of Cancer, Maria Skłodowska-Curie National Research Institute of Oncology Gliwice Branch, Poland

${ }^{4}$ Center for Translational Research and Molecular Biology of Cancer,

Maria Skłodowska-Curie National Research Institute of Oncology Gliwice Branch, Poland
\end{abstract}

\section{Introduction}

The NOD2 protein plays an important role in the function of the immune system. It is active in certain types of immune system cells, including monocytes, macrophages, and dendritic cells, which help to protect the body against foreign invaders, such as viruses and bacteria [1]. NOD2 also regulates the activity of genes that control immune responses and inflammatory reactions, and plays a role in a process called autophagy [3]. The gene that encodes this protein is located on 16q12.1 [2].

The NOD2 3020insC allele is reported in $\sim 7.3 \%$ of the Polish population [4]. In the literature, the presence of NOD2 mutation is associated with increased risk of breast cancer (BC) before the age of 50 years ( 1\%) [5]. This mutation occurs in $\sim 8 \%$ of all BC and increases the risk of DCIS in those aged $<50$ years by five times. The presence of the NOD2 3020insC allele also increases the lifetime risk of colorectal cancer at the age of over 60 years (by over 2-fold), lung cancer ( 2-fold), and ovarian cancer ( 1.5-fold) [6, 9]. The 3020ins C mutation of the NOD2/CARD15 gene may also be a genetic predisposing factor for aggregations of breast and lung cancer [11].

In the literature, there are only a few data describing the association between the presence of NOD2 mutation and clinicopathological factors. The associated factors confirmed in the aforementioned studies were younger age at diagnosis, family history of cancer (especially breast and gastrointestinal cancer) [8], and early-stage disease [6]. In our previous study, the presence of NOD2 (3020insC) in women with BC was characterised by positive predictive factors such as: lymph nodes without metastasis (NO), lower histological grade $(G<3)$, and negative HER2 receptor status (HER2-) [7].

The purpose of the present study was to characterise BC NOD2-mutation carriers at age $\geq 50$ years, according to clinicopathological factors or family history. Patients aged $\geq 50$ years were compared with the control group and with NOD2-mutation carriers at age $<50$ years.

\section{Material and methods}

The analysed group were divided into two subgroups according to patient age: 1 ) < 50 years; and 2) $\geq 50$ years. The clinicopathological factors were analysed, as well as the presence of cancer in family history in younger (age, $<50$ years) $(45.3 \%, n=68 / 150)$ and in older (age, $\geq 50$ years) $(54.7 \%$, $n=82 / 150$ ) patients with BC with confirmed NOD2 (c.3020insC) mutation (GenBank NM_022162.1). Control groups were selected from patients with $\mathrm{BC}$ who tested negative for the mutations $(37.5 \%<50$ years, $n=141$; 
$62.5 \% \geq 50$ years; $n=235 / 376)$. The presence of the most common mutations in BRCA1 (c.68 69delAG, c.181T>G, c.4034delA, c.5266dupC, c.3700_3704del5) (GenBank NM_007294.3), BRCA2 (c.5946delT and c.9403delC) (GenBank NM_000059.3), and CHEK2*1100delC or I157T (GenBank NM_007194.3) genes were excluded. Mutation analysis was carried out by a multiplex allele-specific PCR assay. Genetic diagnostics were conducted between the years 2012 and 2018. All patients gave written, informed consent for genetic examination.

Table 1. Clinicopathological characteristics of all study group breast cancer patients $(n=526)$

\begin{tabular}{|c|c|c|}
\hline \multirow[t]{2}{*}{ Risk factor } & \multicolumn{2}{|c|}{ Breast cancer } \\
\hline & $n$ & $\%$ \\
\hline Age median (range) & \multicolumn{2}{|c|}{52.4 years $(25.5-80.7)$} \\
\hline \multicolumn{3}{|l|}{ Clinical staging nodes } \\
\hline $\mathrm{N}$ positive & 226 & 43.0 \\
\hline N negative & 300 & 57.0 \\
\hline \multicolumn{3}{|l|}{ Tumour size } \\
\hline T3-4 & 83 & 15.8 \\
\hline $\mathrm{T} 1-2$ & 443 & 84.2 \\
\hline \multicolumn{3}{|l|}{ Grade G } \\
\hline G3 & 161 & 30.6 \\
\hline $\mathrm{G} 1+\mathrm{G} 2$ & 365 & 69.4 \\
\hline \multicolumn{3}{|l|}{ ER } \\
\hline Negative & 159 & 30.2 \\
\hline Positive & 367 & 69.8 \\
\hline \multicolumn{3}{|l|}{$P R$} \\
\hline Negative & 196 & 37.3 \\
\hline Positive & 330 & 62.7 \\
\hline \multicolumn{3}{|l|}{ HER2 overexpression } \\
\hline Positive & 215 & 40.9 \\
\hline Negative & 311 & 59.1 \\
\hline \multicolumn{3}{|l|}{ Molecular subtype } \\
\hline Luminal A \& B-type & 236 & 44.9 \\
\hline Others & 290 & 55.1 \\
\hline \multicolumn{3}{|l|}{ Triple negative } \\
\hline Yes & 75 & 14.3 \\
\hline No & 451 & 85.7 \\
\hline \multicolumn{3}{|l|}{ Histological type } \\
\hline Ductal invasive & 401 & 76.2 \\
\hline Lobular invasive ca & 52 & 9.9 \\
\hline Other & 73 & 13.9 \\
\hline \multicolumn{3}{|l|}{ Molecular subtype } \\
\hline Luminal A type & 102 & 19.4 \\
\hline Luminal B- type & 134 & 25.5 \\
\hline Luminal B+ type & 143 & 27.2 \\
\hline Triple negative & 75 & 14.3 \\
\hline Non luminal & 72 & 13.7 \\
\hline
\end{tabular}

All patients were females who were diagnosed, treated, and followed-up at the National Research Institute of Oncology in Gliwice. Patients underwent clinical follow-up examinations every three months in the first two years, every six months afterwards until the fifth year after diagnosis, and every year subsequently. The inclusion criteria were: $B C$ confirmed by microscopic examination; performance status ZUBROD 0-1; age above 18 years; the normal levels of renal and liver function and normal values of bone marrow. The data of age at onset, menopausal status, surgical procedure, disease stage according to TNM classification, histology, oestrogen (ER) and progesterone receptor (PR) status, HER2 status, and contralateral $B C$ were gathered from hospital records and pathology reports. The analysis of patient medical records was performed according to national law regulation.

The median age at diagnosis of all patients was 52.4 years (range, 25.5-80.7 years). Patient clinicopathological characteristics are presented in Table 1. A total of 209 patients were at the age < 50 years and 317 at the age $\geq 50$ years. All patients had good performance status (ZUBROD 0-1). The complete characteristics of patients with regards to demographic and clinicopathological features are presented in Tables 2 and 3.

Statistical analysis was carried out using Statistica13 software. The qualitative features were presented as the percentage of their occurrence and evaluated with Fisher's test and the $\chi^{2}$ test with Yates' correction. Odds ratios (ORs) and 95\% confidence intervals (95\% Cls) were calculated as measures of association between the analysed factors and the presence of NOD2 mutation. The differences were considered significant if the $p$-value was $<0.05$.

\section{Results}

The median age at $B C$ diagnosis for the carriers of the NOD2 mutation was 51.4 years (range, 25.5-80.7 years) and 53.2 years (range, 26.4-78.3 years) for the control group. A total of 209 patients were aged under 50 years: 68 (45.3\%) were NOD2-mutation carriers and 141 (37.2\%) were in the control group.

\section{Group of patients aged $\geq 50$ years}

In the group of patients $\geq 50$ years old, a family history of cancer, including BC, was observed more often in NOD2-mutation carriers compared with the control group of patients (65\% vs. $52 \%$; OR $=1.66 ; p=0.072$, with family history of BC vs. no family history of BC; $32 \%$ vs. $15 \%$; OR $=2.65$; $p=0.002$ ). There were no differences between the control group and NOD2-mutation carriers at age $\geq 50$ years, in those with a family history of other cancer types.

In the group aged $\geq 50$ years, lower tumour size ( $\mathrm{T} 1-$ T2) was observed more often in NOD2-mutation carriers compared with the control group ( $94 \%$ vs. $82 \%$; OR $=3.35$; $p=0.011$ ). Similarly, in patients aged $\geq 50$ years, lymph nodes without metastases were reported insignificantly more frequently in NOD2-mutation carriers (67\% vs. $58 \%, O R=1.48$, $p=0.182)$. Conversely, histological grade G3 tumours (17\% vs. $30 \%, \mathrm{OR}=0.49, p=0.036)$ and HER overexpression $(10 \%$ vs. $49 \%, O R=0.11, p=0.0001$ ) were present significantly 
Table 2. Clinical characteristics of breast cancer patients according to age

\begin{tabular}{|c|c|c|c|c|c|c|c|c|c|c|c|c|}
\hline \multirow[t]{2}{*}{ Risk factor } & \multicolumn{2}{|c|}{$\begin{array}{l}\text { NOD2 } \\
<50 \text { years } \\
(n=68)\end{array}$} & \multicolumn{2}{|c|}{$\begin{array}{c}\text { Control group } \\
<50 \text { years } \\
(n=141)\end{array}$} & \multirow[t]{2}{*}{ OR } & \multirow[t]{2}{*}{$p$} & \multicolumn{2}{|c|}{$\begin{array}{c}\text { NOD2 } \\
\geq 50 \text { years } \\
(n=82)\end{array}$} & \multicolumn{2}{|c|}{$\begin{array}{l}\text { Control group } \\
\geq 50 \text { years } \\
(n=235)\end{array}$} & \multirow[t]{2}{*}{ OR } & \multirow[t]{2}{*}{$p$} \\
\hline & $n$ & $\%$ & $n$ & $\%$ & & & $n$ & $\%$ & $n$ & $\%$ & & \\
\hline Age median (range) & \multicolumn{2}{|c|}{$\begin{array}{c}42.8 \text { years } \\
(25.5-49.9)\end{array}$} & \multicolumn{2}{|c|}{$\begin{array}{c}43.8 \text { years } \\
(26.4-50.0)\end{array}$} & & $0.331^{*}$ & \multicolumn{2}{|c|}{$\begin{array}{c}58.2 \text { years } \\
(50.0-80.7)\end{array}$} & \multicolumn{2}{|c|}{$\begin{array}{c}59.3 \text { years } \\
(50.0-78.3)\end{array}$} & & 0.928 \\
\hline \multicolumn{13}{|l|}{ Menopausal status } \\
\hline Premenopausal & 61 & 89.7 & 129 & 91.5 & 0.81 & 0.798 & 13 & 15.9 & 31 & 13.2 & 1.24 & 0.678 \\
\hline Postmenopausal & 7 & 10.3 & 12 & 8.5 & 1.0 & & 69 & 83.1 & 204 & 86.8 & 1.0 & \\
\hline \multicolumn{13}{|l|}{ Co-morbid condition } \\
\hline Yes & 17 & 25.0 & 46 & 32.6 & 0.69 & 0.335 & 53 & 64.6 & 139 & 59.1 & 1.26 & 0.457 \\
\hline No & 51 & 75.0 & 95 & 67.4 & 1.0 & & 29 & 35.4 & 96 & 40.9 & 1.0 & \\
\hline \multicolumn{13}{|l|}{ Diabetes } \\
\hline Yes & 2 & 2.9 & 2 & 1.4 & 2.11 & 0.597 & 4 & 4.9 & 13 & 5.5 & 0.88 & 1.00 \\
\hline No & 66 & 97.1 & 139 & 98.6 & 1.0 & & 78 & 95.1 & 222 & 94.5 & 1.0 & \\
\hline \multicolumn{13}{|c|}{ Cardiovascular diseases } \\
\hline Yes & 2 & 2.9 & 1 & 0.7 & 4.24 & 0.248 & 9 & 11.0 & 38 & 16.2 & 0.64 & 0.284 \\
\hline No & 66 & 97.1 & 140 & 99.3 & 1.0 & & 73 & 89.0 & 197 & 83.8 & 1.0 & \\
\hline \multicolumn{13}{|l|}{ Viral diseases } \\
\hline Yes & 0 & 0.0 & 5 & 3.5 & 0.0 & 0.176 & 3 & 3.7 & 13 & 5.5 & 0.65 & 0.770 \\
\hline No & 68 & 100 & 136 & 96.5 & 1.0 & & 79 & 96.3 & 222 & 94.5 & 1.0 & \\
\hline \multicolumn{13}{|c|}{ Cancer in family history } \\
\hline Yes & 41 & 60.3 & 83 & 58.9 & 1.06 & 0.963 & 53 & 64.6 & 123 & 52.3 & 1.66 & 0.072 \\
\hline No & 27 & 39.7 & 58 & 41.1 & 1.0 & & 29 & 35.4 & 112 & 47.7 & 1.0 & \\
\hline \multicolumn{13}{|c|}{ Breast cancer in family history } \\
\hline Yes & 17 & 25.0 & 27 & 19.1 & 1.41 & 0.429 & 26 & 31.7 & 35 & 14.9 & 2.65 & 0.002 \\
\hline No & 51 & 75.0 & 114 & 80.9 & 1.0 & & 56 & 68.3 & 200 & 85.1 & 1.0 & \\
\hline \multicolumn{13}{|c|}{ Lung cancer in family history } \\
\hline Yes & 6 & 8.8 & 13 & 9.2 & 0.95 & 0.870 & 6 & 7.3 & 21 & 8.9 & 0.80 & 0.819 \\
\hline No & 62 & 91.2 & 128 & 90.8 & 1.0 & & 76 & 92.7 & 214 & 91.1 & 1.0 & \\
\hline \multicolumn{13}{|c|}{ Gynaecological cancer in family history } \\
\hline Yes & 7 & 10.3 & 12 & 8.5 & 1.23 & 0.870 & 10 & 12.2 & 25 & 10.6 & 1.17 & 0.855 \\
\hline No & 61 & 89.7 & 129 & 91.5 & 1.0 & & 72 & 87.8 & 210 & 89.4 & 1.0 & \\
\hline \multicolumn{13}{|c|}{ Stomach cancer in family history } \\
\hline Yes & 6 & 8.8 & 12 & 8.5 & 1.04 & 0.851 & 8 & 9.8 & 14 & 6.0 & 1.71 & 0.361 \\
\hline No & 62 & 91.2 & 129 & 91.5 & 1.0 & & 74 & 90.2 & 221 & 94.0 & 1.0 & \\
\hline Pancreas cancer in fa & histor & & & & & & & & & & & \\
\hline Yes & 4 & 5.9 & 2 & 1.4 & 4.34 & 0.089 & 2 & 2.4 & 4 & 1.7 & 1.44 & 0.651 \\
\hline No & 64 & 94.1 & 139 & 98.6 & 1.0 & & 80 & 97.6 & 231 & 98.3 & 1.0 & \\
\hline Bowel cancer & & & & & & & & & & & & \\
\hline Yes & 10 & 14.7 & 8 & 5.7 & 2.87 & 0.037 & 9 & 11.0 & 25 & 10.6 & 1.04 & 0.903 \\
\hline No & 58 & 85.3 & 133 & 94.3 & 1.0 & & 73 & 89.0 & 210 & 89.4 & 1.0 & \\
\hline
\end{tabular}

less often in NOD2-mutation carriers. There was also a significant difference between NOD2-mutation carriers and the control group according to $E R-(16 \%$ vs. $32 \%$; OR = 0.39; $p=0.007)$ and $\mathrm{PR}-(23 \%$ vs. $43 \% ; \mathrm{OR}=0.41 ; p=0.003)$ negative steroid receptor status in the group of $\geq 50$ years. In the study group, there was no notable difference between
NOD2-mutation carriers and the control group, according to the $\mathrm{BC}$ histological type (Table 3).

\section{Group of patients aged $<50$ years}

In the group of patients $<50$ years old, there was no difference observed between NOD2-mutation carriers and 
Table 3. Pathological characteristics of the tumours in breast cancer patients according to age

\begin{tabular}{|c|c|c|c|c|c|c|c|c|c|c|c|c|}
\hline \multirow[t]{2}{*}{ Risk factor } & \multicolumn{2}{|c|}{$\begin{array}{l}\quad \text { NOD2 } \\
<50 \text { years } \\
(n=68)\end{array}$} & \multicolumn{2}{|c|}{$\begin{array}{l}\text { Control group } \\
<50 \text { years } \\
(n=141)\end{array}$} & \multirow[t]{2}{*}{ OR } & \multirow[t]{2}{*}{$p$} & \multicolumn{2}{|c|}{$\begin{aligned} & \text { NOD2 } \\
& \geq 50 \text { years } \\
&(n=82)\end{aligned}$} & \multicolumn{2}{|c|}{$\begin{array}{l}\text { Control group } \\
\begin{array}{l}\geq 50 \text { years } \\
(n=235)\end{array}\end{array}$} & \multirow[t]{2}{*}{ OR } & \multirow[t]{2}{*}{$p$} \\
\hline & $n$ & $\%$ & $n$ & $\%$ & & & $n$ & $\%$ & $n$ & $\%$ & & \\
\hline \multicolumn{13}{|l|}{ Clinical staging nodes } \\
\hline $\mathrm{N}$ positive & 25 & 36.8 & 75 & 53.2 & 1 & 0.038 & 27 & 32.9 & 99 & 42.1 & 1 & 0.182 \\
\hline $\mathrm{N}$ negative & 43 & 63.2 & 66 & 46.8 & 1.95 & & 55 & 67.1 & 136 & 57.9 & 1.48 & \\
\hline \multicolumn{13}{|l|}{ Tumour size } \\
\hline T3-4 & 11 & 16.2 & 25 & 17.7 & 1 & 0.934 & 5 & 6.1 & 42 & 17.9 & 1 & 0.011 \\
\hline $\mathrm{T} 1-2$ & 57 & 83.8 & 116 & 82.3 & 1.12 & & 77 & 93.9 & 193 & 82.1 & 3.35 & \\
\hline \multicolumn{13}{|l|}{ Grade G } \\
\hline G3 & 27 & 39.7 & 50 & 35.5 & 1.20 & 0.658 & 14 & 17.1 & 70 & 29.8 & 0.49 & 0.036 \\
\hline $\mathrm{G} 1+\mathrm{G} 2$ & 41 & 60.3 & 91 & 64.5 & 1 & & 68 & 82.9 & 165 & 70.2 & 1 & \\
\hline \multicolumn{13}{|l|}{ ER } \\
\hline Negative & 16 & 23.5 & 54 & 38.3 & 0.50 & 0.049 & 13 & 15.9 & 76 & 32.3 & 0.39 & 0.007 \\
\hline Positive & 52 & 76.5 & 87 & 61.7 & 1 & & 69 & 84.1 & 159 & 67.7 & 1 & \\
\hline \multicolumn{13}{|l|}{ PR } \\
\hline Negative & 21 & 30.9 & 56 & 39.7 & 0.68 & 0.277 & 19 & 23.2 & 100 & 42.6 & 0.41 & 0.003 \\
\hline Positive & 47 & 69.1 & 85 & 60.3 & 1 & & 63 & 76.8 & 135 & 57.4 & 1 & \\
\hline \multicolumn{13}{|l|}{ HER2 overexpression } \\
\hline Positive & 15 & 22.1 & 76 & 53.9 & 0.24 & 0.0001 & 8 & 9.8 & 116 & 49.4 & 0.11 & 0.0001 \\
\hline Negative & 53 & 77.9 & 65 & 46.1 & 1 & & 74 & 90.2 & 119 & 50.6 & 1 & \\
\hline \multicolumn{13}{|l|}{ Molecular subtype } \\
\hline Luminal A \& B-type & 41 & 60.3 & 42 & 29.8 & 3.58 & 0.0001 & 64 & 78.0 & 89 & 37.9 & 5.83 & 0.0001 \\
\hline Others & 27 & 39.7 & 99 & 70.2 & 1 & & 18 & 22.0 & 146 & 62.1 & 1 & \\
\hline \multicolumn{13}{|l|}{ Triple negative } \\
\hline Yes & 12 & 17.6 & 23 & 16.3 & 1.10 & 0.965 & 10 & 12.2 & 30 & 12.8 & 0.95 & 0.953 \\
\hline No & 56 & 82.4 & 118 & 83.7 & 1 & & 72 & 87.8 & 205 & 87.2 & 1 & \\
\hline \multicolumn{13}{|l|}{ Histological type } \\
\hline Ductal invasive & 54 & 79.4 & 110 & 78.0 & 1 & & 61 & 74.4 & 176 & 74.9 & 1 & \\
\hline Lobular invasive ca & 7 & 10.3 & 12 & 8.5 & 1.19 & 0.932 & 8 & 9.8 & 25 & 10.6 & 0.92 & 0.977 \\
\hline Other & 7 & 10.3 & 19 & 13.5 & 0.75 & 0.702 & 13 & 15.8 & 34 & 14.5 & 1.10 & 0.926 \\
\hline \multicolumn{13}{|l|}{ Molecular subtype } \\
\hline Luminal A type & 18 & 26.5 & 10 & 7.1 & 1 & & 40 & 48.8 & 34 & 14.5 & 1 & \\
\hline Luminal B-type & 23 & 33.8 & 32 & 22.7 & 0.40 & 0.0885 & 24 & 29.3 & 55 & 23.4 & 0.37 & 0.005 \\
\hline Luminal B+ type & 11 & 16.2 & 48 & 34.0 & 0.13 & 0.0001 & 5 & 6.1 & 79 & 33.6 & 0.05 & 0.0001 \\
\hline Triple negative & 12 & 17.6 & 23 & 16.3 & 0.29 & 0.034 & 10 & 12.2 & 30 & 12.8 & 0.28 & 0.005 \\
\hline Non luminal & 4 & 5.9 & 28 & 19.9 & 0.08 & 0.0001 & 3 & 3.6 & 37 & 15.7 & 0.07 & 0.0001 \\
\hline
\end{tabular}

the control group, according to those with a family history of cancer ( $60 \%$ vs. $59 \%$; OR $=1.06 ; p=0.963)$, particularly those with a family history of BC ( $25 \%$ vs. $19 \%$; OR $=1.41$; $p=0.429$ ). Conversely, history of colorectal cancer was observed significantly more often in younger NOD2-mutation carriers compared with the control group (15\% vs. $6 \% ; \mathrm{OR}=2.87 ; p=0.037$ ). A similar tendency was reported in those with a family history of pancreatic cancer $(5.9 \%$ vs. $1.4 \%$; OR $=4.34 ; p=0.089)$. There were no differences between younger patients and the control group, based on a family history of stomach cancer ( $8.8 \%$ vs. $8.5 \%$; $\mathrm{OR}=1.04 ; p=0.851)$. Similar results were reported in those with a family history of lung cancer (8.8\% vs. 9.2\%; $\mathrm{OR}=0.95 ; p=0.870$ ) or gynaecological cancer (10.3\% vs. $8.5 \% ; \mathrm{OR}=1.23 ; p=0.870$ ) (Table 2).

There was no difference between younger NOD2-mutation carriers and the control group, according to tumour size (T1-T2) ( $84 \%$ vs. $82 \%$; OR $=1.12 ; p=0.934)$. Lymph nodes without metastases (63\% vs. $47 \%$; OR $=1.95$; $p=0.038$ ) were significantly more frequently observed in NOD2-mutation carriers compared with the control group at this age. In the group of individuals of $<50$ years old, histological grade G3 was non-significantly more often observed in NOD2-mutation carriers $(p=0.658)$. Conversely, 
Table 4. Univariate and multivariate logistic regression

\begin{tabular}{|c|c|c|c|c|}
\hline \multirow[t]{2}{*}{ Characteristics } & \multicolumn{2}{|c|}{ Univariate analysis } & \multicolumn{2}{|c|}{ Multivariate analysis } \\
\hline & OR $(95 \% \mathrm{Cl})$ & $p$-value & OR $(95 \% \mathrm{Cl})$ & $p$-value \\
\hline Age $\geq 50$ years vs. $<50$ years & $0.72(0.49-1.06)$ & 0.098 & $0.61(0.40-0.93)$ & 0.020 \\
\hline Status: post- vs. premenopausal & $0.76(0.52-1.11)$ & 0.158 & & \\
\hline T3-T4 vs. T1-T2 & $0.55(0.31-0.99)$ & 0.044 & & \\
\hline $\mathrm{N}+$ vs. NO & $0.62(0.42-0.91)$ & 0.016 & & \\
\hline G3 vs. G1-G2 & $0.80(0.53-1.22)$ & 0.304 & & \\
\hline$E R+v s . E R O$ & $2.20(1.40-3.48)$ & 0.001 & $2.10(1.30-3.41)$ & 0.003 \\
\hline$P R+$ vs. PRO & $1.95(1.29-2.96)$ & 0.002 & & \\
\hline HER2 positive vs. HER2 negative & $0.17(0.11-0.28)$ & 0.0001 & $0.17(0.11-0.28)$ & 0.0001 \\
\hline \multicolumn{5}{|l|}{ Breast cancer patients age $<50$ years } \\
\hline T3-T4 vs. T1-T2 & $0.90(0.41-1.95)$ & 0.934 & & \\
\hline $\mathrm{N}+$ vs. NO & $0.51(0.28-0.93)$ & 0.038 & & \\
\hline G3 vs. G1-G2 & $1.20(0.66-2.17)$ & 0.658 & & \\
\hline$E R+v s . E R O$ & $2.02(1.05-3.88)$ & 0.049 & $1.94(0.98-3.83)$ & 0.058 \\
\hline$P R+$ vs. PRO & $1.47(0.80-2.73)$ & 0.277 & & \\
\hline HER2 positive vs. HER2 negative & $0.24(0.12-0.47)$ & 0.0001 & $0.25(0.13-0.48)$ & 0.0001 \\
\hline \multicolumn{5}{|l|}{ Breast cancer patients: age $\geq 50$ years } \\
\hline T3-T4 vs. T1-T2 & $0.30(0.11-0.78)$ & 0.011 & $0.35(0.13-0.96)$ & 0.041 \\
\hline$N+$ vs. NO & $0.67(0.40-1.14)$ & 0.182 & & \\
\hline G3 vs. G1-G2 & $0.49(0.26-0.92)$ & 0.036 & & \\
\hline$E R+v s . E R O$ & $2.54(1.32-4.87)$ & 0.007 & $2.03(1.01-4.08)$ & 0.046 \\
\hline$P R+v s . P R O$ & $2.46(1.38-4.36)$ & 0.003 & & \\
\hline HER2 positive vs. HER2 negative & $0.11(0.05-0.24)$ & 0.0001 & $0.12(0.05-0.26)$ & 0.0001 \\
\hline
\end{tabular}

HER2 overexpression was reported significantly less often in NOD2-mutation carriers (22\% vs. $54 \%$; OR $=0.24 ; p=$ $0.0001)$ at this age. There was a significant difference between NOD2-mutation carriers and the control group, according to $\mathrm{ER}-(24 \%$ vs. $38 \%$; OR $=0.50 ; p=0.049)$ negative steroid receptor status, while there was no differences for PR- (31\% vs. $40 \%$; OR $=0.68 ; p=0.277)$ negative steroid receptor status. Conversely, there was no difference between NOD2-mutation carriers and the control group, according to $\mathrm{BC}$ histological type - ductal invasive carcinoma (79\% vs. $78 \%)$ in the group of individuals $<50$ years (Table 3).

\section{Breast cancer molecular subtypes}

The presence of BC molecular subtypes in NOD2-mutation carriers and in the control group of patients differ from each other significantly $(p=0.0001)$. This is due to the differences in the presence of HER2 overexpression, positive oestrogen $(E R+)$, and progesterone $(\mathrm{PR}+)$ steroid receptor status in both groups (NOD2-mutation carriers and the control group). The most commonly observed BC subtypes in the present study among NOD2-mutation carriers were luminal A and luminal B HER2(-). These subtypes were observed in $60 \%$ of younger NOD2-mutation carriers $(<50$ years) and in 78\% of NOD2-mutation carriers over 50 years of age $(p=0.018)$. In the group $<50$ years of age, luminal A (26\% vs. $7 \%$ ) and luminal B HER2(-) (34\% vs. $23 \%)$ BC subtypes were reported more frequently in patients with NOD2 mutation compared with the control group (Fig. 1). Similarly, in the group of individuals $\geq 50$ years old, luminal A (49\% vs. $15 \%)$ and luminal B HER2(-) (29\% vs. 23\%) subtypes were reported more often in patients with NOD2 mutation (Fig. 2). The risk of the presence of other BC subtypes than luminal A among NOD2-mutation carriers is lower compared with the control group, independently of patients' age (Table 3).

\section{Logistic regression analysis results}

Factors that were significantly associated with the presence of NOD2 mutation among BC subgroups, in patients aged $\geq 50$ years and $<50$ years, were detected. Patients $\geq$ 50 years of age were characterised by lower tumour size (T1-T2), lower histological grade (G1-G2), positive steroid receptor status (ER+ and $\mathrm{PR}+$ ), and tumours without HER2 overexpression. Conversely, younger (< 50 years) NOD2-mutation carriers were characterised by the deficiency of lymph node metastases (NO), ER+ status, and tumours without HER2 overexpression (Table 3).

Multivariate logistic regression analysis results for NOD2 mutation among patients with $\mathrm{BC}$ is shown in Table 4 . Among patients with $\mathrm{BC}$ at the age $\geq 50$ years, the presence of NOD2 mutation was significantly associated with lack of HER2 overexpression $(\mathrm{OR}=0.12 ; p=0.0001)$, lower tumour size $(\mathrm{T} ; \mathrm{OR}=0.35 ; p=0.041)$, and $\mathrm{ER}+$ status 
Table 5. Pathological characteristics of the tumours in breast cancer patients with NOD2 mutation according to age

\begin{tabular}{|c|c|c|c|c|c|c|}
\hline \multirow[t]{2}{*}{ Risk factor } & \multicolumn{2}{|c|}{$\begin{array}{c}\text { NOD2 } \\
<50 \text { years } \\
(n=68)\end{array}$} & \multicolumn{2}{|c|}{$\begin{aligned} & \text { NOD2 } \\
\geq & 50 \text { years } \\
& (n=82)\end{aligned}$} & \multirow{2}{*}{$\begin{array}{c}\text { NOD2 } \\
<50 \text { years vs. } \\
\text { NOD2 } \geq 50 \text { years } \\
\text { OR }\end{array}$} & \multirow[t]{2}{*}{$p$} \\
\hline & $n$ & $\%$ & $n$ & $\%$ & & \\
\hline \multicolumn{7}{|l|}{ Clinical staging nodes } \\
\hline N positive & 25 & 36.8 & 27 & 32.9 & 1.18 & 0.749 \\
\hline $\mathrm{N}$ negative & 43 & 63.2 & 55 & 67.1 & 1 & \\
\hline \multicolumn{7}{|l|}{ Tumour size } \\
\hline T3-4 & 11 & 16.2 & 5 & 6.1 & 2.97 & 0.063 \\
\hline $\mathrm{T} 1-2$ & 57 & 83.8 & 77 & 93.9 & 1 & \\
\hline \multicolumn{7}{|l|}{ Grade G } \\
\hline G3 & 27 & 39.7 & 14 & 17.1 & 3.20 & 0.004 \\
\hline $\mathrm{G} 1+\mathrm{G} 2$ & 41 & 60.3 & 68 & 82.9 & 1 & \\
\hline \multicolumn{7}{|l|}{ ER } \\
\hline Negative & 16 & 23.5 & 13 & 15.9 & 1.63 & 0.328 \\
\hline Positive & 52 & 76.5 & 69 & 84.1 & 1 & \\
\hline \multicolumn{7}{|l|}{ PR } \\
\hline Negative & 21 & 30.9 & 19 & 23.2 & 1.48 & 0.380 \\
\hline Positive & 47 & 69.1 & 63 & 76.8 & 1 & \\
\hline \multicolumn{7}{|l|}{ HER2 overexpression } \\
\hline Positive & 15 & 22.1 & 8 & 9.8 & 2.62 & 0.043 \\
\hline Negative & 53 & 77.9 & 74 & 90.2 & 1 & \\
\hline \multicolumn{7}{|l|}{ Molecular subtype } \\
\hline Luminal A \& B-type & 41 & 60.3 & 64 & 78.0 & 0.43 & 0.029 \\
\hline Others & 27 & 39.7 & 18 & 22.0 & 1 & \\
\hline \multicolumn{7}{|l|}{ Triple negative } \\
\hline Yes & 12 & 17.6 & 10 & 12.2 & 1.54 & 0.479 \\
\hline No & 56 & 82.4 & 72 & 87.8 & 1 & \\
\hline \multicolumn{7}{|l|}{ Molecular subtype } \\
\hline Luminal A type & 18 & 26.5 & 40 & 48.8 & 1 & \\
\hline Luminal B-type & 23 & 33.8 & 24 & 29.3 & 2.13 & 0.095 \\
\hline Luminal B+ type & 11 & 16.2 & 5 & 6.1 & 4.89 & 0.009 \\
\hline Triple negative & 12 & 17.6 & 10 & 12.2 & 2.67 & 0.093 \\
\hline Non luminal & 4 & 5.9 & 3 & 3.7 & 2.96 & 0.215 \\
\hline
\end{tabular}

$(\mathrm{OR}=2.03 ; p=0.046)$. However, among patients with $\mathrm{BC}$ below the age of 50 years the presence of NOD2 mutation was significantly associated with HER2-negative status $(\mathrm{OR}=0.25 ; p=0.0001)$ and insignificantly with ER-positive status $(\mathrm{OR}=1.94 ; p=0.058)$.

Multivariate analysis has shown, for all study groups, that the older age $(\mathrm{OR}=0.61 ; p=0.020)$, ER+ status $(\mathrm{OR}=2.10 ; p=0.003)$, and tumours without HER2 overexpression $(\mathrm{OR}=0.17 ; p=0.0001)$ were risk factors for NOD2 mutation in patients with BC (Table 4).

\section{NOD2-mutation carriers at the age of $<50$ years} vs. $\geq 50$ years

The comparison of patients with NOD mutations in age groups $<50$ and $\geq 50$ years indicated a tendency towards higher incidence of negative factors in the group of young- er patients with BC (Table 5). BC tumours with G3 (40\% vs. $17 \% ; \mathrm{OR}=3.20 ; p=0.004)$ and with HER2 overexpression (22\% vs. $10 \%$; OR $=2.62 ; p=0.043$ ) were observed significantly more often among younger patients with NOD2 mutation. The tendency towards the presence of larger tumour size (T3-T4) in younger NOD2-mutation carriers was also observed.

Multivariate analysis of pathological factors in the group of individuals with NOD2 mutation has shown that only G3 (OR $=3.22 ; p=0.003)$ was significantly associated with the presence of NOD2 mutation in younger patients.

\section{Discussion}

In the present study, NOD2-mutation carriers at age $\geq 50$ years were compared with the control group and with the younger ( $<50$ years) subgroup of patients with NOD2 


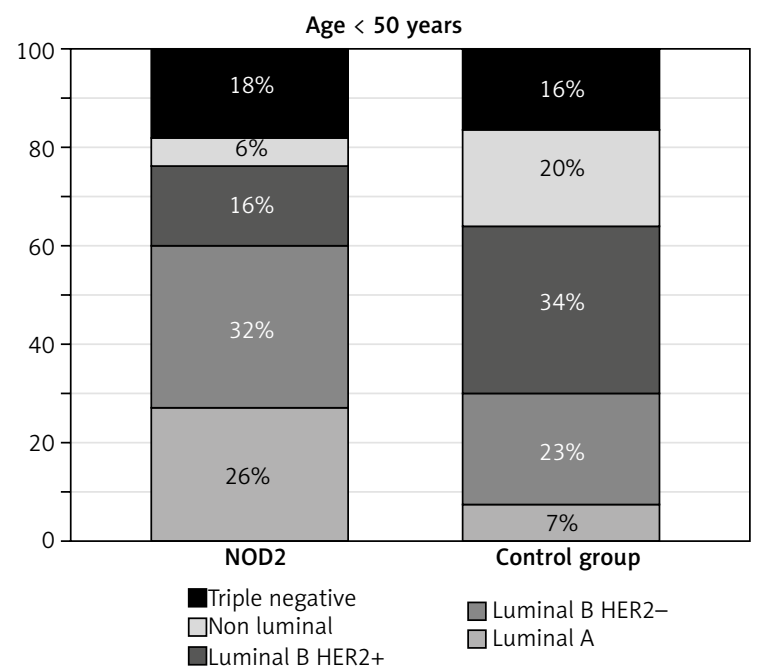

Fig. 1. Breast cancer molecular subtypes in group of patients aged $<50$ years

mutation; according to the clinicopathological factors, such as hormone status ER, PR, HER2, tumour size, the presence of lymph node metastases, and history of cancer in the family.

The insignificant association between the NOD2 3020ins C mutation and a family history of BC was reported by Huzarski et al. [5]. The 3020insC mutation of the NOD2/CARD15 gene may also be a genetic predisposing factor for aggregations of breast and lung cancer. Lener et al. reported that the presence of NOD2 mutation was higher in patients with $B C$ who had a first- or second-degree relative diagnosed with lung cancer compared with patients who had no relatives affected by lung cancer [11]. Janiszewska et al. [8] suggested that the NOD2 3020insC mutation may increase the risk of developing gastrointestinal cancer rather than BC. Similarly, in a study conducted by Kurzawski et al., the frequency of the 3020insC mutation in 250 patients with non-hereditary nonpolyposis colorectal cancer at age $>50$ years was significantly higher in comparison to the control group (OR, 2.23; $p=0.0046)$ [9]. In another study, the risk of gastric cancer in NOD2 3020ins C-mutation carriers at age $>50$ years was more than doubled $(\mathrm{OR}=2.479 ; p=0.022)$ and was almost even three-fold greater among women [10]. In a previous analysis, the presence of NOD2 mutation was associated with an increased risk of a family history of breast, renal, and colorectal cancer [7]. In the present analysis, a family history of cancer, including BC, was observed more often in NOD2-mutation compared with the control group; in patients at age $\geq 50$ years. In the group of patients at age $<50$ years, the presence of cancer in family history was similar between NOD2-mutation carriers and the control group. Conversely, a family history of colorectal and pancreatic cancer was observed significantly more often in younger NOD2-mutation carriers compared with the control group.

The association between NOD2 mutation and clinicopathological factors in cancer was described only in a few data $[7,12]$. Lakatos et al. conducted a study on patients with colorectal cancer and reported no association be-

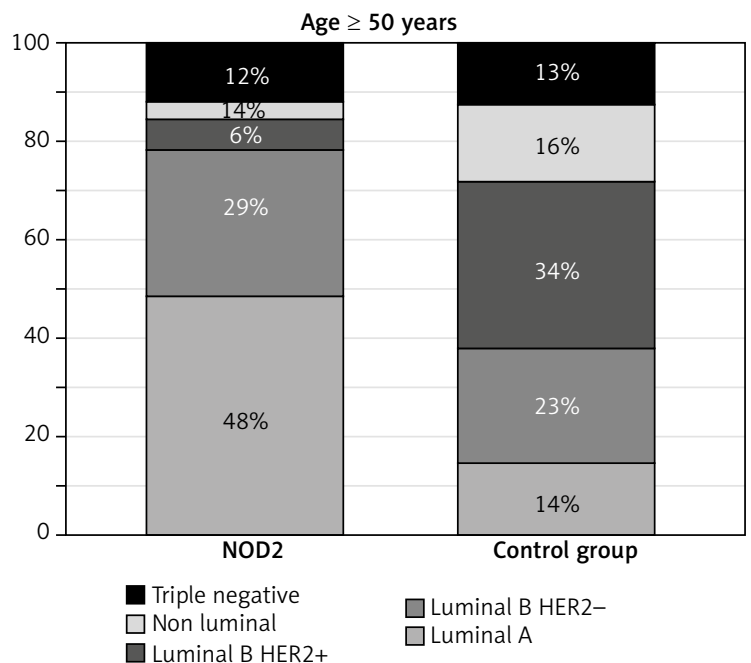

Fig. 2. Breast cancer molecular subtypes in group of patients aged $\geq 50$ years

tween clinicopathological factors (such as patient's age or symptoms at diagnosis) and the CARD15/NOD2 variants carrier status [12]. In a previous analysis, no differences between NOD2 (3020insC) mutation carriers and non-carriers were reported, according to co-morbid condition, drugs, tumour size, steroid receptor status, and five-year overall survival. NOD2 mutation in women with BC was characterised by lymph nodes without metastasis (NO), lower histological grade $(\mathrm{G}<3)$, and negative HER2 receptor status (HER2-) [7].

In the present analysis, the subgroup of BC NOD2-mutation carriers at age $\geq 50$ years was characterised by lower tumour size (T1-T2), lower histological grade (G1-G2), positive steroid receptor status (ER+ and $\mathrm{PR}+$ ), and tumours without HER2 overexpression. Patients at age $<50$ years are characterised by lymph nodes without metastases, ER+ status, and tumours without HER2 overexpression. There was no difference between NOD2-mutation carriers and the control group observed, according to the $\mathrm{BC}$ histological type.

ER+ status and tumours without HER2 overexpression were mostly characteristic of patients with BC with NOD2 mutation, independently of age, in comparison to the control group. Multivariate logistic regression has improved these results and has showed that patients at age $\geq 50$ years have a lower risk of NOD2 mutation compared with the younger age group $(\mathrm{OR}=0.61 ; p=0.020)$.

In the group of patients with NOD2 mutation at age $\geq 50$ years, histological grades G3 and HER overexpression were observed significantly less often compared with younger NOD2-mutation carriers.

Luminal A and luminal B HER2 BC subtypes were most characteristic of patients with NOD2 mutation, independently of age. This analysis was conducted on a larger group of patients, in comparison to the previous study.

The present study has potential limitations. The most important limitation is the group size. Due to some differences between the previous and present studies, a larger group of patients is required. HER2-negative status was characteristic of patients with BC with NOD2 mutation, 
independently of age, compared with the control group, in the previous and present studies. The other factors such as NO and G1-G2 were reported from univariate analysis in the present study, but in different subgroups. NO is observed significantly more often in NOD2-mutation carriers at age $<50$ years and G1-G2 in the subgroup of individuals at age $\geq 50$ years. In a previous study, patients without NOD2 mutation and NOD2-mutation carriers had similar ages at diagnosis. This can be the cause of the differences.

\section{Conclusions}

A family history of BC was characteristic of NOD2-mutation carriers at age $\geq 50$ years. HER2 overexpression and ER status were significantly associated with the presence of NOD2 mutation in patients with BC, independently of age. Luminal A or luminal B HER2-negative BC subtypes were most characteristic of patients with NOD2 mutation, independently of age.

In NOD2-mutation carriers at the age $\geq 50$ years, the presence of higher tumour size, G3 or HER2 overexpression were lower compared with younger patients. Multivariate analysis has shown that only $G$ significantly differentiates both groups of NOD2-mutation carriers.

The authors declare no conflict of interest.

\section{References}

1. Inohara N, Nuñez G. NODs intracellular proteins involved in inflammation and apoptosis. Nat Rev Immunol 2003; 3: 371-382.

2. Hugot JP, Laurent-Puig P, Gower-Rousseau C, et al. Mapping of a susceptibility locus for Crohn's disease on chromosome 16. Nature 1996; 29: 821-823.

3. Al Nabhani Z, Dietrich G, Hugot JP, Barreau F. NOD2: The intestinal gate keeper. PLoS Pathog 2017; 13: e1006177.

4. Lubiński J, Huzarski T, Kurzawski G et al. The 3020insC allele of NOD2 predisposes to cancer of multiple organs. Hered Cancer Clin Practice 2005; 3: 59-63.

5. Huzarski T, Lener M, Domagala W, et al. The 3020insC allele of NOD2 predisposes to early-onset breast cancer. Breast Cancer Res Treat 2005; 89: 91-93.

6. Kurzawski G, Suchy J, Cybulski C, et al. DNA tests for variants conferring low or moderate increase in the risk of cancer. Szczecin 2017: 1-10.

7. Huszno J, Kołosza Z, Tęcza K, Pamuła-Piłat J, Mazur M, Grzybowska E. Comparison between NOD2 gene mutation carriers (3020insC) and non-carriers in breast cancer patients: a clinicopathological and survival analysis. Arch Med Sci Civil Dis 2018; 3: e10-e15.

8. Janiszewska H, Haus O, Lauda-Swieciak A, Bak A, Mierzwa T, Sir J, Laskowski R. The NOD2 3020insC Mutation in Women with Breast Cancer from the Bydgoszcz Region in Poland. First Results. Hered Cancer Clin Pract 2006; 15: 4: 15-19.

9. Kurzawski G, Suchy J, Kładny J, et al. The NOD2 3020insC mutation and the risk of colorectal cancer. Cancer Res 2004; 64: 1604-1606.

10. Teodorczyk U, Cybulski C, Jakubowska A, et al. Mutations and polymorphisms of genes moderate increase in gastric cancer risk. Hered Cancer Clin Pract 2012; 10 (Suppl 3): A22.

11. Lener MR, Oszutowska D, Castaneda J, et al. Prevalence of the NOD2 3020insC mutation in aggregations of breast and lung cancer. Breast Cancer Res Treat 2006; 95: 141-145.

12. Lakatos PL, Hitre E, Szalay F, et al. Common NOD2/CARD15 variants are not associated with susceptibility or the clinicopathological characteristics of sporadic colorectal cancer in Hungarian patients. BMC Cancer 2007; 7: 54.

\section{Address for correspondence}

\section{Joanna Huszno}

Genetic Outpatient Clinic

Maria Skłodowska-Curie National Research Institute of Oncology Gliwice Branch

15 Wybrzeże Armii Krajowej St.

44-101 Gliwice, Poland

e-mail: joahus@wp.pl

Submitted: 9.04 .2020

Accepted: 14.04.2020 